\title{
ANALISIS KINERJA PERPAJAKAN DAERAH DI KOTA MEDAN
}

\author{
Dede Ruslan \\ Fakultas Ekonomi Universitas Negeri Medan \\ Email: dras ruslan@yahoo.com
}

\begin{abstract}
Delegation of authority taxation (tax assignment) was good to regional governments tend to date still lacks clear standards and universal. Tax assignment and restructuring of taxes and levies in a sustainable course can only be done by revising Law No. 28 of 2009 which is the basis in the management of local taxes and levies. How the performance of local taxation in Medan running has been the material of interest to be studied. Assessment approach used in this study diguankan kualitaitif research and quantitative research. Whereas in other research used to obtain a quantitative description on the contributions and the rate of development of local taxes to the local tax revenue and the performance of Medan, through analytical tools tax elasticity, tax ratio and TPI. The results showed that the performance of local taxes through tax elasticity is known that the average percentage change in local taxes to the percentage change in the GDP amounted to $1.99 \%$, while the ratio of the tax does not show improvement every year. Tax ratio that existed during the period 2011-2015 ranged from $0.62 \%$ to $0.85 \%$. For the effectiveness of the tax is relatively stable with ratanya average at 0.79 and when viewed from the level of efficiency since the year 2011 to 2015 ranged from $0 \%$ to $2.15 \%$. In an average rate of $0.04 \%$ CCER only. These values were lower and included in the category of good..
\end{abstract}

Keywords : tax performance, tax elasticity, tax ratio and CCER.

\section{PENDAHULUAN}

$D$ endelegasian kewenangan perpajakan (tax assignment) yang baik kepada pemerintah daerah cenderung sampai saat ini masih kurang memiliki standar yang jelas dan universal. Meski demikian, tax

assignment merupakan keniscayaan sejalan dengan fungsi-fungsi pemerintahan yang didelegasikan ke daerah terutama untuk meningkatkan kemandirian, akuntabilitas, efisiensi penyediaan barang publik, dan 
kesejahteraan masyarakat. Di Indonesia, peningkatan rasio pajak daerah terhadap pendapatan daerah menjadi salah satu faktor yang ikut mendorong pemerintah untuk terus melakukan tax assignment. Di samping tax assignment, aspek lain yang sangat penting dalam kebijakan desentralisasi fiskal Indonesia adalah restrukturisasi pajak dan retribusi daerah.

Tax assignment dan restrukturisasi pajak dan retribusi daerah secara berkelanjutan tentu saja hanya bisa dilakukan dengan merevisi UndangUndang No. 28 Tahun 2009 yang merupakan dasar dalam pengelolaan pajak daerah dan retribusi daerah. Oleh karena itu, kajian mendalam terhadap kemungkinan pendaerahan beberapa jenis pajak daerah seperti Pajak Tanah dan Bangunan di sektor Perkebunan, Perhutanan, dan Pertambangan (tidak termasuk tubuh bumi) dan penerapan sistem untuk $\mathrm{PPh}$, serta restrukturisasi pajak dan retribusi daerah dengan mengelompokkan pajak-pajak sejenis, seperti Pajak Hotel, Pajak Restoran, Pajak Hiburan, dan Pajak Penerangan Jalan (PPJ), dan Pajak Reklame menjadi pajak barang dan jasa tertentu, dan menggabungkan semua jenis retribusi perizinan di daerah menjadi business license tax. Apabila revisi Undang-Undang ini telah selesai maka Undang-undang 28 Tahun 2009 tentang Pajak dan Retribusi Daerah sudah barang tentu mengalami penyesuaian. Agar kajian ini dapat memiliki jangkauan waktu cukup panjang maka antisipasi revisi UU 28 Tahun 2009 ini masuk sebagai faktor yang dipertimbangkan dalam pelaksanaan studi ini.

Tujuan perubahan Undang-Undang No 28 Tahun 2009 tentang Pajak Daerah dan Retribusi Daerah : (1) Memperbaiki sistem pemungutan pajak daerah dan retribusi daerah, (2) Penguatan perpajakan daerah (local taxing empowerment), (3) Meningkatkan efektivitas pengawasan pungutan daerah, (4) Menyempurnakan pengelolaan pajak daerah dan retribusi daerah.

Sebagaimana diketahui, Undang-undang Nomor 28 Tahun 2009 tentang Pajak Daerah dan Retribusi Daerah (UU PDRD) mengamanatkan bahwa, PBB sektor Perdesaan dan Perkotaan akan dikelola oleh Pemerintah Daerah paling lambat mulai bulan Januari 2014, sedangkan BPHTB dikelola oleh Pemerintah Daerah mulai Januari 2011. Di kalangan praktisi PBB termasuk pencermatan dari widyaiswara Pusdiklat Pajak yang kompetensinya mengajar materi $\mathrm{PBB}$ dan $\mathrm{BPHTB}$, terdapat beberapa pasal 
yang menggelitik untuk dikomentari antara lain pasal 81, pasal 87 ayat (4) dan pasal 90 ayat (1) huruf $d$ beserta penjelasan dari masing-masing pasal tersebut. Adapun tujuan dari Undang-undang Pajak Daerah dan Retribusi Daerah adalah memberikan kewenangan yang lebih besar kepada daerah dalam perpajakan dan retribusi sejalan dengan semakin besarnya tanggung jawab Daerah dalam penyelenggaraan pemerintahan dan pelayanan kepada masyarakat, meningkatkan akuntabilitas daerah dalam penyediaan layanan dan penyelenggaraan pemerintahan dan sekaligus memperkuat otonomi daerah, serta memberikan kepastian bagi dunia usaha mengenai jenis-jenis pungutan daerah dan sekaligus memperkuat dasar hukum pemungutan pajak daerah dan retribusi daerah. Permasalahan yang terlebih dahulu perlu dianalisis untuk mencermati masalah tersebut diatas diantaranya adalah melihat bagaimana kinerja perpajakan daerah di Kota Medan berjalan selama ini.

Menurut Sumitro (1988) Pajak adalah iuran rakyat pada kas negara berdasarkan Undang-Undang (yang dapat di paksakan) dengan tidak mendapat jasa timbal (kontra prestasi) yang langsung dapat di tunjukkan dan yang di gunakan untuk membayar pengeluaran umum"."Dapat di paksakan" mempunyai arti,apabila utang pajak tidak di bayar,utang tersebut di tagih dengan kekerasan, seperti surat paksa, sita, lelang dan sandera.

Sementara itu menurut Brotodiharjo,R (1982) pajak adalah iuran rakyat kepada negara (yang dapat di paksakan) yang terutang oleh wajib pajak membayarnya berdasarkan peraturan-peraturan,dengan tidak mendapat prestasi kembali yang langsung dapat di tunjuk dan yang dapat di gunakan untuk membiayai pengeluaran umum berhubungan dengan tugas negara untuk menyelenggarakan pemerintah".

Menurut Undang-Undang Nomor 34 tahun 2004 Perubahan Atas UndangUndang No. 18 tahun 1997 tentang Pajak Daerah dan Retribusi Daerah, yang dimaksud dengan Pajak Daerah adalah Iuran wajib yang dilakukan oleh orang pribadi atau badan kepada daerah tanpa imbalan langsung yang seimbang, yang dapat dipaksakan berdasarkan peraturan perundangundangan untuk membiayai penyelenggaraan pemerinta daerah dan pembangunan daerah. 
Menurut Davey (1988:39-40) ada beberapa pengertian tentang pajak daerah antara lain (1) Pajak yang dipungut oleh Pemerintah Daerah dengan pengaturan dari daerah sendiri; (2) Pajak yang dipungut berdasarkan peraturan nasional tetapi penetapan tarifnya dilakukan oleh Pemerintah Daerah; (3) Pajak yang ditetapkan dan dipungut oleh Pemerintah Daerah; (4) Pajak yang dipungut dan diadministrasikan oleh pemerintah pusat tetapi hasilnya diberikan kepada, dibagihasilkan, atau dibebani pungutan tambahan (opsen) oleh Pemerintah Daerah. Sedangkan menurut Undangundang Nomor 34 Tahun 2000 tentang Pajak Daerah dan Retribusi Daerah, pengertian Pajak Daerah adalah "iuran wajib yang dilakukan oleh orang pribadi atau badan kepada Daerah tanpa imbalan langsung yang seimbang, yang dapat dipaksakan berdasarkan peraturan perundangundangan yang berlaku,yang digunakan untuk membiayai penyelenggaraan pemerintahan Daerah dan pembangunan Daerah".

Pajak merupakan komponen penerimaan yang sangat penting. Menurut Mikesell and Hay $(1969,75)$ : "Taxes are of special importance because :(1) they provide a verry large portion of the revenue of governmental units on all levels, (2) they are compulsory contributions to the cost of government, whether the affected taxpayer approves or disapproves of the levy.

Efektivitas merupakan suatu ukuran yang menyatakan seberapa jauh target (kuantitas, kualitas dan waktu) yang telah dicapai oleh manajemen, yang mana target tersebut sudah ditentukan terlebih dahulu(Sedarmayanti, 2009: 59). Dimana semakin besar persentase target yang dicapai, maka semakin tinggi efektivitasnya. Efektivitas pajak adalah perbandingan antara penerimaan pajak dengan target (potensi) penerimaan pajak yang telah dicapai (realisasi pajak).Efektivitas pajak daerah menunjukkan kemampuan pemerintah daerah dalam mengumpulkan pajak daerah sesuai dengan jumlah penerimaan pajak daerah yang ditargetkan. Jadi, efektivitas yang dimaksud adalah seberapa besar realisasi penerimaan pajak daerah berhasil mencapai target yang seharusnya dicapai pada suatu periode tertentu (Puspitasari, 2014 dalam Halim, 2004). Untuk menghitung tingkat efektivitas dalam pemungutan pajak dapat menggunakan rumus sebagai berikut (Puspitasari, 2014 dalam Halim, 2004):

$$
\text { Efektivitas Pajak }=\frac{\text { Realiasasi Penerimaan Pajak }}{\text { Target Penerimaan Pajak }} \times 100 \%
$$




\section{METODOLOGI KAJIAN}

Pendekatan kajian yang digunakan dalam penelitian ini diguankan penelitian kualitaitif dan penelitian kuantitaf. Sedangkan dalam peneltian kuantitaif digunakan untuk memperoleh gambaran secara objektif tentang kontribusi dan laju perkembangan pajak daerah terhadap PAD serta kinerja pajak daerah Kota Medan, melalui alat analitis

$$
\begin{gathered}
\text { Tax Elasticity }=\frac{\% \text { PerubahanPenerimaanPajakDaerah }}{\% \text { PerubahanPDRB }} \\
\text { Tax Ratio }=\frac{\text { PenerimaanPajakDaerah }}{\text { PDRB }} \\
T P I=\frac{\text { RealisasiPenerimaanPajak }}{\text { TargetPenerimaanPajak }}
\end{gathered}
$$

\section{HASIL KAJIAN DAN PEMBAHASAN}

Kinerja Perpajakan Daerah Kota Medan

Penerimaan Asli Daerah (PAD) adalah sumber penerimaan daerah yang dikelola dan dimanfaatkannya sepenuhnya oleh daerah. Pendapatan asli daerah merupakan sumber keuangan daerah yang digali dari dalam wilayah daerah yang bersangkutan yang terdiri dari pajak daerah, retribusi daerah, hasil perusahaan milik daerah dan hasil pengelolaan kekayaan daerah yang dipisahkan serta lain-lain pendapatan asli daerah yang sah. Oleh karena itu perkembangannya berkaitan erat dengan upaya fiscal (fiscal effort) yang dilakukan pemerintah daerah dalam menggali dan mengembangkan potensi penerimaan yang dimiliki oleh daerah lainnya. Gambaran komposisi PAD Kota Medan periode tahun 2010-2015 dapat dilihat pada tabel di bawah ini

Tabel 1 Komposisi PAD Kota Medan Tahun 2010-2015 (Dlm Rp Milliar)

\begin{tabular}{llllllll}
\hline \multicolumn{2}{c}{ Komposisi Pendapatan } & \multicolumn{6}{c}{ Realisasi } \\
$\quad$ Asli Daerah & 2010 & 2011 & 2012 & 2013 & 2014 & 2015 \\
\hline 1 & Pajak Daerah & 308,12 & 609,38 & 892,67 & 881,35 & 962,73 & 996,03 \\
2 & Retribusi Daerah & 212,16 & 236,69 & 127,84 & 188,46 & 171,01 & 200,16
\end{tabular}




\begin{tabular}{|c|c|c|c|c|c|c|c|}
\hline 3 & $\begin{array}{l}\text { Pengelolaan } \\
\text { Kekayaan Daerah } \\
\text { yang dipisahkan }\end{array}$ & 9,53 & 11,73 & 9,78 & 9,5 & 5,7 & 8,52 \\
\hline & $\begin{array}{l}\text { Lain-Lain PAD yang } \\
\text { sah }\end{array}$ & 59,13 & 127,27 & 117,61 & 126,86 & 244,81 & 185,01 \\
\hline & PAD (Rp. Milyar) & 588,94 & 995,07 & 1147,9 & 1206,17 & 1384,25 & 1489,72 \\
\hline
\end{tabular}

Sumber : Laporan Realisai APBD Kota Medan : Badan Pengelola Keuangan Daerah (Berbagai tahun, diolah)

Berdasarkan Tabel 1 diatas diperoleh gambaran bahwa realisasi PAD dari tahun ketahun mengalami fluktuasi dengan rata-rata pertumbuhan PAD untuk tahun 2010-2015 adalah sebesar 22,36\%. Pertumbuhan PAD tertinggi terjadi pada tahun 2011 yaitu sebesar $68,96 \%$ dan pertumbuhan terendah pada tahun 2013 yaitu sebesar 5,08\%. Pertumbuhan untuk tahun 2014 ke 2015 adalah sebesar 7,62\%. Pergerakan PAD Kota Medan tahun digambarkan dalam gambar 1 sebagai berikut :

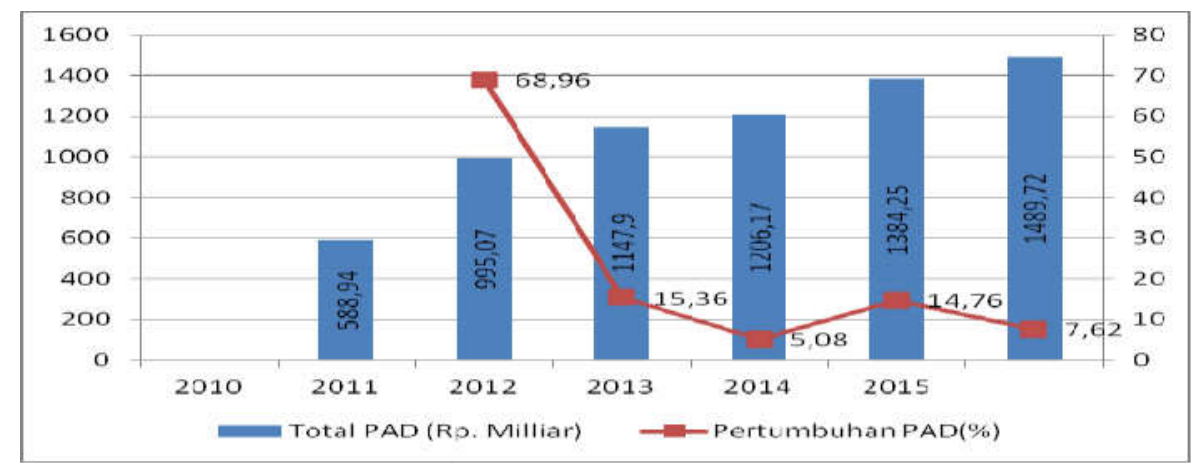

Sumber : Laporan Realisai APBD Kota Medan : Badan Pengelola Keuangan Daerah (Berbagai tahun, diolah)

Gambar 1. PAD dan Pertumbuhan

Untuk mengidentifikasi dan menganalisis sektor-sektor mana saja dari PAD yang potensial untuk dikembangkan dalam rangka meningkatkan penerimaan pendapatan asli daerah di Pemerintah Kota Medan, berikut rincian perkembangan sumber pendapatan asli daerah yang ditunjukkan dalam tabel 2. Berdasarkan tabel 2 menunjukkan bahwa sumber-sumber PAD untuk Kota Medan selama periode 2010-2015, yaitu pajak daerah, retribusi daerah, pendapatan hasil pengelolaan kekayaan daerah yang dipisahkan, lain-lain pendapatan asli daerah yang sah mengalami terus peningkatan 
Tabel 2. Rincian Perkembangan Sumber Pendapatan Asli Daerah Pemerintah Kota Medan

\begin{tabular}{|c|c|c|c|c|c|c|}
\hline \multirow{2}{*}{ No } & \multirow{2}{*}{ Uraian } & \multicolumn{5}{|c|}{ Jumlah } \\
\hline & & 2011 & 2012 & 2013 & 2014 & 2015 \\
\hline \multicolumn{2}{|c|}{ Pendapatan Pajak Daerah } & 609,38 & 892,67 & 881,35 & 962,73 & 996,03 \\
\hline 1 & Pajak Hotel & 58,60 & 65,86 & 76,94 & 82,05 & 8,26 \\
\hline 2 & Pajak Restoran & 70,67 & 83,18 & 93,13 & 107,53 & 124,40 \\
\hline 3 & Pajak Hiburan & 16,24 & 21,59 & 27,16 & 30,12 & 31,16 \\
\hline 4 & Pajak Reklame & 28,00 & 26,98 & 23,35 & 17,71 & 12,83 \\
\hline 5 & Pajak Penerangan Jalan & 172,67 & 146,30 & 167,03 & 190,55 & 222,31 \\
\hline 6 & Pajar Parkir & 5,91 & 6,86 & 7,45 & 8,31 & 12,41 \\
\hline 7 & Pajak Air & 3,07 & 7,94 & 8,21 & 9,07 & 10,79 \\
\hline 8 & Pajak BPHTB & 254,22 & 259,11 & 243,75 & 228,39 & 201,81 \\
\hline 9 & Pajak PBB & 0,00 & 30,79 & 26,59 & 30,02 & 29,92 \\
\hline \multicolumn{2}{|c|}{ Pendapatan Retribusi Daerah } & 236,69 & 127,84 & 188,46 & 171,01 & 200,16 \\
\hline 1 & Retribusi Jasa Umum & 114,35 & 33,33 & 39,69 & 40,94 & 49,23 \\
\hline 2 & Retribusi Jasa Usaha & 19,61 & 14,94 & 12,52 & 12,18 & 7,45 \\
\hline 3 & Retribusi Perijinan Terpadu & 102,73 & 79,57 & 136,25 & 117,89 & 143,48 \\
\hline \multicolumn{2}{|c|}{$\begin{array}{l}\text { Pendapatan Hasil Pengelolaan } \\
\text { Kekayaan }\end{array}$} & 11,73 & 9,78 & 9,50 & 5,71 & 8,52 \\
\hline 1 & $\begin{array}{l}\text { Bagian Laba atas Penyertaan } \\
\text { Modal pada Perusahaan Milik } \\
\text { Daerah/BUMD }\end{array}$ & 0,15 & 0,18 & 0,56 & 0,00 & 0,00 \\
\hline 2 & $\begin{array}{l}\text { Bagian Laba atas penyertaan } \\
\text { modal pada Perusahaan BUMD }\end{array}$ & 11,35 & 9,26 & 8,94 & 5,71 & 8,52 \\
\hline 3 & $\begin{array}{l}\text { Bagian Laba atas penyertaan } \\
\text { modal pada Perusahaan } \\
\text { Swasta }\end{array}$ & 0,23 & 0,34 & 0,00 & 0,00 & 0,00 \\
\hline \multicolumn{2}{|c|}{ Lain-lain Pendapatan Asli Daerah } & 137,27 & 117,61 & 126,86 & 244,81 & 285,01 \\
\hline 1 & Pendapatan Jasa Giro & 15,77 & 7,15 & 4,18 & 9,22 & 16,96 \\
\hline 2 & Komisi & 0,02 & 0,00 & 0,00 & 0,00 & 0,00 \\
\hline 3 & $\begin{array}{l}\text { Pendapatan Denda } \\
\text { Keterlambatan Pekerjaan }\end{array}$ & 3,15 & 0,00 & 0,00 & 0,00 & 0,00 \\
\hline 4 & Pendapatan Denda Pajak & 1,83 & 2,04 & 1,81 & 2,55 & 1,09 \\
\hline 5 & Pendapatan dari Pengembalian & 0,95 & 12,48 & 11,34 & 18,18 & 33,19 \\
\hline 6 & Fasilitas Sosial & 0,02 & 0,00 & 0,00 & 0,00 & 0,00 \\
\hline 7 & Penerimaan Lain-lain & 4,72 & 95,94 & 109,53 & 214,86 & 233,77 \\
\hline 8 & $\begin{array}{l}\text { Pendapatan dari kekurangan } \\
\text { bagi hasil propinsi }\end{array}$ & 110,81 & 0,00 & 0,00 & 0,00 & 0,00 \\
\hline
\end{tabular}

Sumber : Laporan Realisasi APBD, Badan Pengelola Keuangan Kota Medan (Berbagai tahun) Diolah

Jika di perhatikan dari sumber-sumber pandapatan asli daerah tersebut, pajak daerah dan retribusi daerah masih mendominasi dalam penerimaan pendapatan asli daerah di kota Medan bila dibandingkan dengan sumber

QE Journal | Vol.05 - No. 04 Desember 2016 - 197 
penerimaan yang lain yakni pendapatan hasil pengelolaan kekayaan daerah yang dipisahkan dan lain-lain pendapatan asli daerah yang sah yang masih memberi kontribusi kecil. Besarnya kontribusi laba BUMD terhadap PAD dapat dijadikan indikator kuat atau lemahnya BUMD dalam suatu daerah. Berdasarkan keterangan diatas maka dapat diperoleh sektor-sektor PAD yang perlu dikembangkan adalah pajak daerah dan retribusi daerah. Selama periode 2011-2015, pajak daerah mengalami pertumbuhan yang melambat, artinya terjadi penurunan yang cukup signifikan sebagaimana ditunjukkan dalam grafik berikut ini.

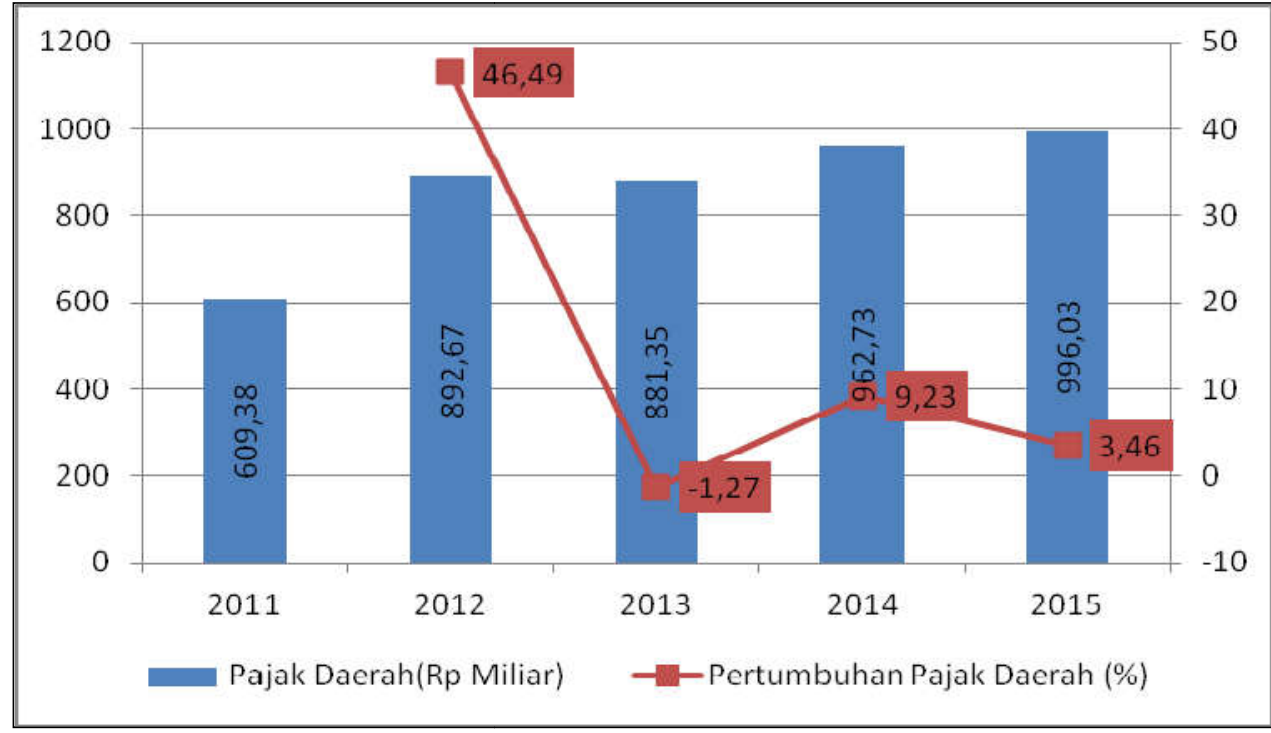

Sumber: Laporan Realisasi APBD, Badan Pengelola Keuangan Kota Medan (Berbagai tahun) Diolah

Gambar 2. Perkembangan Penerimaan Pajak Daerah Tahun Anggaran 2011-2015

Dalam periode tersebut Pajak Daerah mengalami rata-rata pertumbuhan sebesar 14,48\%, dengan pertumbuhan terendah pada periode tahun 2013 dengan pertumbuhan negatif sebesar $-1,27 \%$ dan tertinggi pada periode tahun 2012 sebesar 46,49\%.

Berdasarkan tabel 2 di atas maka dapat dihitung besarnya kontribusi masing-masing jenis pajak daerah terhadap jumlah total penerimaan pajak daerah selama kurun waktu 2011-2015 yang akan disajikan dalam tabel berikut : 
Tabel 3. Kontribusi Jenis Pajak terhadap Pendapatan Pajak Daerah

\begin{tabular}{|c|c|c|c|c|c|c|c|}
\hline \multirow{2}{*}{ No } & \multirow{2}{*}{ Uraian } & \multicolumn{5}{|c|}{ Jumlah } & \multirow{2}{*}{$\begin{array}{l}\text { Rata- } \\
\text { rata }\end{array}$} \\
\hline & & 2011 & 2012 & 2013 & 2014 & 2015 & \\
\hline \multicolumn{2}{|c|}{ Pendapatan Pajak Daerah } & 100,00 & 100,00 & 100,00 & 100,00 & 100,00 & \\
\hline 1 & Pajak Hotel & 9,62 & 7,38 & 8,73 & 8,52 & 8,26 & 8,50 \\
\hline 2 & Pajak Restoran & 11,60 & 9,32 & 10,57 & 11,17 & 12,49 & 11,03 \\
\hline 3 & Pajak Hiburan & 2,67 & 2,42 & 3,08 & 3,13 & 3,13 & 2,88 \\
\hline 4 & Pajak Reklame & 4,59 & 3,02 & 2,65 & 1,84 & 1,29 & 2,68 \\
\hline 5 & $\begin{array}{l}\text { Pajak Penerangan } \\
\text { Jalan }\end{array}$ & 28,34 & 16,39 & 18,95 & 19,79 & 22,32 & 21,16 \\
\hline 6 & Pajar Parkir & 0,97 & 0,77 & 0,85 & 0,86 & 1,25 & 0,94 \\
\hline 7 & Pajak Air & 0,50 & 0,89 & 0,93 & 0,94 & 1,08 & 0,87 \\
\hline 8 & Pajak BPHTB & 41,72 & 29,03 & 27,66 & 23,72 & 20,26 & 28,48 \\
\hline 9 & Pajak PBB & 0,00 & 30,79 & 26,59 & 30,02 & 29,92 & 23,46 \\
\hline
\end{tabular}

Sumber: Laporan Realisasi APBD, Badan Pengelola Keuangan Kota Medan (Berbagai tahun) Diolah

Terlihat pada tabel di atas rata-rata kontributor terbesar penerimaan pajak daerah di Kota Medan 2011-2015 adalah Pajak BPHTB sebesar 28,48\% dengan nilai nominal Rp 246,37 milyar diikuti Pajak PBB sebesar 23,46\% dengan nilai nominal Rp 199,55 milyar, kemudian secara berturut-turut Pajak Penerangan Jalan (21,16\%), Pajak Restoran (11,03\%) dan Hotel $(8,5 \%)$. Selanjutnya Pajak Hiburan dan Pajak Reklama masing-masing sebesar $2,88 \%$ dan 2,68\%. Hal ini sesuai dengan penelitian yang dilakukan oleh Salomo dan Ikhsan (2002:95) yang menyebutkan bahwa salah satu jenis pajak daerah yang memberikan kontribusi terbesar bagi penerimaan pajak daerah yaitu Pajak Penerangan Jalan. Selanjutnya Salomo dan Ikhsan (2002:96) menjelaskan bahwa jenis-jenis pajak daerah tersebut mempunyai potensi untuk dikembangkan di masa mendatang.

Berdasarkan data tersebut diatas, di Kota Medan jenis pajak daerah yang memiliki potensi untuk dikembangkan adalah pajak BPHTB, Pajak PBB, Pajak Penerangan jalan, Pajak restoran dan Pajak Hotel. Hal ini tentunya sangat berimplikasi pada jenis investasi yang menarik untuk dikembangkan di Kota Medan yaitu potensi investasi di bidang Properti terkait dengan sektor Perumahan yang akan dapat meningkatkan pajak 
PBB dan BPHTB, lalu investasi di sektor restoran berikut dengan sektor turunannya berupa investasi kuliner dan investasi di sektor perhotelan.

Agar lebih mudah memahami kontribusi penerimaan setiap jenis pajak daerah terhadap seluruh penerimaan pajak daerah maka penulis juga menyajikan dalam bentuk gambar berikut ini :

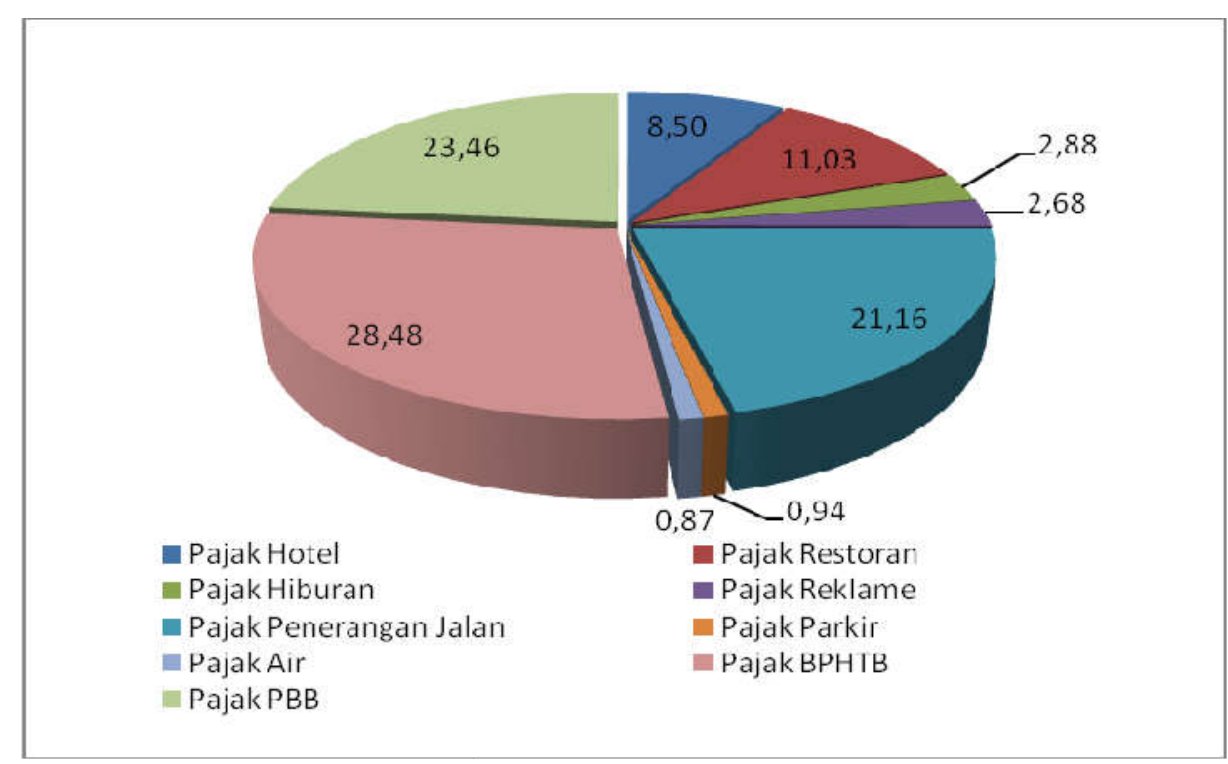

Gambar 3. Kontribusi Setiap Jenis Pajak Daerah Terhadap Pajak Daerah

Berdasarkan data tersebut diatas, di Kota Medan jenis pajak daerah yang memiliki potensi untuk dikembangkan adalah pajak BPHTB, Pajak PBB, Pajak Penerangan jalan, Pajak restoran dan Pajak Hotel. Hal ini tentunya sangat berimplikasi pada jenis investasi yang menarik untuk dikembangkan di Kota Medan yaitu potensi investasi di bidang Properti terkait dengan sektor Perumahan yang akan dapat meningkatkan pajak PBB dan BPHTB, lalu investasi di sektor restoran berikut dengan sektor turunannya berupa investasi kuliner dan investasi di sektor perhotelan.

Berdasarkan data dan uraian diatas, selanjutnya dapat dianalisis kinerja pajak daerah yang terdi dari tiga hal yaitu analisis mengenai upaya pajak (tax effort) yang mencakup elastisitas pajak daerah (tax elasticity) dan rasio pajak (tax ratio), kemudian tax effectivenes (hasil guna) serta terakhir adalah tax efficiency.

Tax Elasticity (Elastisitas Pajak Daerah)

QE Journal | Vol.05 - No. 04 Desember 2016 - 200 
Analisis elastisitas pajak atau yang sering juga disebut tax bouyancy dengan melihat seberapa besar perbandingan persentase perubahan penerimaan pajak daerah dengan persentase perubahan PDRB. Hal ini adalah untuk melihat kepekaan perubahan PDRB tahun depan yang disebabkan perubahan penerimaan pajak daerah tahun sekarang. Agar lebih mudah memahami perhitungannya maka di bawah ini disajikan perhitungannya dengan tabel sebagai berikut :

Tabel 4. Tax Elasticity

\begin{tabular}{cccccc}
\hline \multirow{2}{*}{ Tahun } & Pajak Daerah & PDRB Harga Konstan & \multicolumn{2}{c}{ Pertumbuhan } & $\begin{array}{c}\text { Tax } \\
\text { Elasticity }\end{array}$ \\
\cline { 2 - 6 } & (Rp Milyar) & (Rp Milyar) & \multicolumn{2}{c}{$(\%)$} & $(\%)$ \\
\hline 2011 & 609,38 & 97674,56 & 46,49 & 7,67 & 6,06 \\
2012 & 892,67 & 105162,01 & $-1,27$ & 5,36 & $-0,24$ \\
2013 & 881,35 & 110794,43 & 9,23 & 6,06 & 1,52 \\
2014 & 962,73 & 117507,60 & 3,46 & 5,76 & 0,60 \\
2015 & 996,03 & 124277,41 & 1,99 \\
\hline \multicolumn{5}{c}{ Rata-rata } \\
\hline
\end{tabular}

Sumber : Diolah

Dari tabel di atas terlihat bahwa rata-rata presentase perubahan pajak daerah terhadap presentase perubahan PDRB adalah sebesar 1,99\%. Hal ini berarti selama periode 2011-2015, jika pajak daerah tahun sekarang sebesar 1\% maka PDRB pada tahun yang akan datang akan meningkat sebesar 1,99\%. Angka ini terlihat sangat kecil. Hal ini berarti setiap terdapat perubahan PDRB, maka penerimaan pajak daerah tidak berubah secara signifikan, dengan demikian jika Pemerintah Kota Medan mengambil kebijakan dengan tujuan meningkatkan penerimaan pajak daerah dalam rangka meningkatkan PDRB adalah kebijakan yang kurang tepat. Karena konstribusi PAD terhadap PDRB sangat kecil yaitu rata rata untuk lima tahun terakhir hanya sebesar 0,78\%. Namun jika upaya peningkatan pajak daerah adalah dalam rangka meningkatkan PAD adalah tepat, sebab rata-rata kontribusi Pajak Daerah terhadap PAD cukup signifikan, yaitu sebesar $69,70 \%$. Hal ini cukup penting karena PAD dipandang sebagai ciri kemandirian suatu daerah. Hal ini juga berarti jika upaya peningkatan pajak daerah dalam rangka meningkatkan Penerimaan Asli Daerah, maka hal tersebut merupakan kebijakan yang tepat, sebab rata-rata kontribusi Pajak Daerah terhadap Penerimaan Asli Daerah tahun 2011-2014 cukup signifikan yaitu sebesar $69,70 \%$. Hal ini cukup penting karena Penerimaan Asli Daerah dipandang sebagai ciri kemandirian suatu Daerah. 


\section{Tax Ratio (Rasio Pajak)}

Selanjutnya Ukuran kinerja perpajakan pada umumnya menggunakan rasio pajak (tax ratio), yaitu dengan cara membagi realisasi penerimaan pajak dengan Produk Domestik Regional Bruto (PDRB). Oleh karena itu, terkait dengan rasio pajak, Produk Domestik Regional Bruto (PDRB) menggambarkan jumlah pendapatan potensial yang dapat dikenai pajak. PDRB juga menggambarkan kegiatan ekonomi masyarakat yang jika berkembang dengan baik merupakan potensi yang baik bagi pengenaan pajak di wilayah tersebut. Mengetahui angka-angka rasio pajak di Kota Medan akan membantu dalam menganalisis secara sederhana hubungan antara pajak daerah Kota Medan dengan PDRB-nya. Dengan Rasio pajak dapat digunakan untuk mengukur tingkat kepatuhan masyarakat dalam membayarkan pajak, mengukur kinerja perpajakan, dan melihat potensi pajak yang dimiliki. Sehingga semakin tinggi tax ratio suatu daerah menggambarkan semakin tinggi kemandirian suatu daerah. Semakin mandiri suatu daerah berarti semakin tinggi partisipasi masyarakat dalam membayar pajak yang nantinya akan meningkatkan penerimaan Pendapatan Asli Daerah (PAD) Kota Medan. Adapun Rasio Pajak Daerah Kota Medan terhadap PDRB ditunjukkan dalam tabel sevai berikut:

Tabel 5. Tax Ratio

\begin{tabular}{cccccc}
\hline \multirow{2}{*}{ Tahun } & Pajak Daerah & PDRB Harga Konstan & \multicolumn{2}{c}{ Pertumbuhan } & \multicolumn{1}{c}{ Tax Ratio } \\
\cline { 2 - 6 } & (Rp Milyar) & (Rp Milyar) & \multicolumn{2}{c}{$(\%)$} & $(\%)$ \\
\hline 2011 & 609,38 & 97674,56 & & & 0,62 \\
2012 & 892,67 & 105162,01 & 46,49 & 7,67 & 0,85 \\
2013 & 881,35 & 110794,43 & $-1,27$ & 5,36 & 0,80 \\
2014 & 962,73 & 117507,60 & 9,23 & 6,06 & 0,82 \\
2015 & 996,03 & 124277,41 & 3,46 & 5,76 & 0,80 \\
\hline \multicolumn{7}{c}{ Rata-rata } \\
\hline
\end{tabular}

Tax Ratio yang diperoleh Kota Medan dapat dilihat pada table di atas. Terlihat pada tabel lima tahun terakhir dari 2011-2015 tax ratio yang diperoleh Kota Medan sebagai salah satu ukuran kinerja pajak daerah tidak menunjukan peningkatan setiap tahunnya. Tax ratio yang ada selama periode 2011-2015 berkisar antara 0,62\% sampai 0,85\%, dimana tak ratio setiap tahunnya hanya sebesar 0,01 atau rata-rata sebesar $0,82 \%$. Hal ini belum menunjukan upaya pajak daerah (tax effort) masih kecil atau belum signifikan. Sebagai patokan, Devas (1983:67) mengatakan bahwa 
apabila tax effort (upaya pajak) yang diperoleh mencapai $2 \%$ maka upaya pajak yang dilakukan adalah baik.

Tax Effectiveness (Hasil Guna Pajak)

Pengukuran efektifitas pajak dilakukan dengan menggunakan Tax Performance Index (TPI). TPI ini Mengukur hubungan antara hasil pungut suatu pajak dengan potensi hasil pajak itu sendiri, dengan anggapan semua wajib pajak membayar pajaknya masing-masing. TPI diperoleh dengan membandingkan Realisasi Penerimaan Pajak Daerah dengan Rencana Penerimaan Pajak Daerah. Pengukuran efektivitas ini dilakukan dengan data mengenai target penerimaan pajak daerah. Pengukuran efektivitas diperoleh dengan membandingkan Realisasi Penerimaan Pajak Daerah dengan Rencana Penerimaan Pajak Daerah yang diperoleh dari Dinas Pendapatan Daerah Kota Medan. Berikut ini pengukuran Tax Performance Index (TPI), untuk tahun 2011-2015

Tabel 6. Perhitungan Tax Performance Index

\begin{tabular}{cccc}
\hline \multirow{2}{*}{ Tahun } & Realisasi Pajak Daerah & Rencana Pajak Daerah & \multirow{2}{*}{ TPI } \\
\cline { 2 - 3 } & (Rp Milyar) & (Rp Milyar) & \\
\hline 2011 & 609,38 & 585,03 & 1,04 \\
2012 & 892,67 & 1088,00 & 0,82 \\
2013 & 881,35 & 1190,00 & 0,74 \\
2014 & 962,73 & 1167,40 & 0,82 \\
2015 & 996,03 & 1267,10 & 0,79 \\
\hline \multicolumn{3}{c}{ Rata-rata } & 0,79 \\
\hline
\end{tabular}

Sumber : Diolah

Ratio TPI untuk menghitung tingkat efektifitas berdasarkan tabel perhitungan Tax Performance Index di atas menunjukan tingkat efektifitas yang cenderung berfluktuasi yang relatif stabil. Tahun 2011 terlihat tingkat efektifitas yang dicapai pada tahun ini adalah sebesar 1,04. Penerimaan Pajak pada tahun itu sebesar nominal Rp 609,38 milyar sedangkan rencana penerimaan sebesar Rp.585,03, pada tahun tersebut penerimaan pajak dapat dikatakan efektif, namun untuk tahun 2012 hingga tahun 2015 TPI mengalami penurunan yang cukup signifikan menjadi tidak efektif, dimana penerimaan pajak daerah pada tahun-tahun tersebut lebih kecil dari rencananya. Sehingga untuk tahun 2012 sampai dengan 2015 Dinas Pendapatan Kota Medan dapat dinyatakan tidak berhasil dalam mencapai target yang direncanakan. 


\section{Tax Effeciency (Daya Guna Pajak)}

Untuk menghitung efisiensi pajak (daya guna pajak) maka penulis akan sajikan dalam tabel 7. Terlihat pada tabel 7 nilai CCER yang ada sejak Tahun 2011 hingga 2015 berkisar antara 0\% hingga 2,15\%. Secara rata-rata angka CCER hanya sebesar 0,04\%. Angka ini termasuk rendah dan termasuk dalam katagori yang baik, sebab Devas (Salomo dan Ikhsan, 2002:128) mengatakan bahwa bila angka CCER tidak lebih dari 20\% berarti masih cukup baik dan dapat dikatakan efisien.

Tabel 7 Tax Effeciency yang di ukur dari Cost of Collection Effeiciency Ratio

\begin{tabular}{cccc}
\hline \multirow{2}{*}{ Tahun } & Realisasi Pajak Daerah & Biaya Pemungutan PD & \multirow{2}{*}{ CCER (\%) } \\
\cline { 2 - 3 } & (Rp Milyar) & (Rp Milyar) & \\
\hline 2011 & 609,38 & 13,11 & 2,15 \\
2012 & 892,67 & 1,40 & 0,16 \\
2013 & 881,35 & 0,00 & 0,00 \\
2014 & 962,73 & 0,00 & 0,00 \\
2015 & 996,03 & 0,00 & 0,00 \\
\hline \multicolumn{3}{c}{ Rata-rata } & 0,04 \\
\hline
\end{tabular}

Sumber : Diolah

\section{SIMPULAN DAN SARAN}

Simpulan

Secara umum kinerja perpajakan daerah Kota Medan diperoleh gambaran bahwa realisasi PAD dari tahun ketahun mengalami fluktuasi dengan rata-rata pertumbuhan PAD untuk tahun 2010-2015 adalah sebesar 22,36\%. Dari PAD tersebut pajak daerah dan retribusi daerah masih mendominasi dalam penerimaan pendapatan asli daerah di kota Medan dengan rata-rata pertumbuhan sebesar 14,48\% untuk periode 2011-2015. Kontribusi terbesar terbesar penerimaan pajak daerah di Kota Medan 2011-2015 adalah Pajak BPHTB sebesar 28,48\%.

Dilihat dari kinerja pajak daerah, ditunjukkan melalui elastisitas pajak diketahui bahwa rata-rata presentase perubahan pajak daerah terhadap presentase perubahan PDRB adalah sebesar 1,99\%, sedangkan dari sisi rasio pajak tidak menunjukan peningkatan setiap tahunnya. Tax ratio yang ada selama periode 2011-2015 berkisar antara 0,62\% sampai 0,85\%. Untuk tingkat efektivitas pajak relatif stabil dengan rata ratanya sebesar 0,79 dan jika dilihat dari tingkat efisiensinya sejak Tahun 2011 hingga 2015 berkisar antara $0 \%$ hingga 2,15\%. Secara rata-rata angka CCER hanya 
sebesar $0,04 \%$. Angka ini termasuk rendah dan termasuk dalam katagori yang baik.

Saran

Mencermati perkembangan penerimaan pajak daerah yang cukup besar, seyogyanya Pemerintah Daerah Kota Medan melalui Dinas Pendapatan Daerah agar lebih menggali lagi penerimaan pajak daerah dengan cara melaksanakan ekstensifikasi dan intensifikasi pajak daerah dengan cara :

1) Memperluas basis penerimaan

2) Meningkatkan kinerja fiskus dengan cara melakukan pelaksanaan tahap-tahap administrasi pemungutan pajak dengan benar, melakukan penetapan perencanaan penerimaan yang berdasarkan potensi pajak yang sebenarnya dan meningkatkan efisiensi biaya pemungutan

\section{DAFTAR PUSTAKA}

Basri, Faisal H. Perekonomian Indonesia Menjelang Abad XXI, Distorsi, Peluang dan Kendala. Jakarta : Erlangga 1997.

Bird, Richard M. \& Francois Vaillancourt. Desentralisasi Fiskal Di NegaraNegara Berkembang, terjemahan Alimizan Ulfa, Gramedia, Jakarta, 2000

Cocrhane, Glynn. Policies for Strengtening Goverment in Developing Countries., World Bank Staff Working Papers. No 582. Washington D.C. 1983

Davey. K.J. Pembiayaan Pemerintahan : Praktek-praktek Internasional dan Relevansinya Bagi Dunia Ketiga. UI Press, Jakarta, 1988.

Devas, Nick dkk. Keuangan Pemerintah Daerah Di Indonesia. UI Press. Jakarta.1989

Dimock, Marshal Edward and Gladys Ogden Dimock. Administrasi Negara. Diterjemahkan oleh Husni Thamrin Pane. Cetakan Kelima. Rineka Cipta. Jakarta 1982

Dumairy, Perekonomian Indonesia, Penerbit Erlangga, Jakarta, 1994

Effendi, Elfian. Jangan Menunggu Kapal Pecah, salah urus hutan, Otonomi Daerah dan Desentralisasi Fiskal. Lembaga Penerbit FEUI, Jakarta, 2001 
Handayaningrat, Soewarno. Pengantar Study Administrasi Dan Manajemen.. CV Haji Masagung. Jakarta.1990

........Administrasi Pemerintahan Dalam Pembangunan Nasional. Cetakan Kesepuluh. CV Haji Masagung. Jakarta. 1994

Hidayat, Syarif dan Carunia Mulya Firdausy. Exploring Indonesian Local State-Elite's orientation towards local autonomy. Japan International Cooperation Agency. Jakarta, 2002

Hoessein, Bhenyamin. Hubungan Penyelenggaraan Pemerintahan Pusat dengan Pemerintahan Daerah, Jurnal Bisnis dan Birokrasi, Jakarta, Juli 2000.

Ida, Laode. Otonomi Daerah, Demokrasi \& Clean Government. PSPK, Jakarta, 2000

Kasim, Azhar. Pengukuran Efektivitas Dalam Organisasi. Pusat Antar Universitas Ilmu-Ilmu Sosial Universitas Indonesia. Jakarta. 1993

Kaho, Josef Riwu. Prospek Otonomi Daerah di Negara Republik Indonesia, Identifikasi Beberpa Faktor Yang Mempengaruhi Penyelenggaraannya. Raja Grafindo Persada, Jakarta, 1997

Kartasasmita, Ginanjar. Pembangunan Untuk Rakyat Memadukan Pertumbuhan Dan Pemerataan. Jakarta : Cidesindo 1996

Kelley, Patrick L. and Oliver Oldman. Income Tax Administration. The Foundation Press Inc. New York. 1973

Koswara, E. Untuk Demokrasi Dan Kemandirian Rakyat. Yayasan Pariba. Jakarta. 2001

Koswara, E. Menyongsong Pelaksanaan Otonomi Daerah Berdasarkan UU No 22 Tahun 1999. Suatu Telaah menyangkut Kebijakasanaan dan Kompleksitasnya. Analisis CSIS No.1 Jakarta

Kuncoro, Mudrajad. Otonomi dan Pembangunan Daerah, Reformasi, Perencanaan, Strategi dan Peluang. Erlangga. Jakarta. 2003

Lubis, Hari S.B. dan Martani Huseini. Teori Organisasi., Pusat Antar Universitas Ilmu-Ilmu Sosial Universitas Indonesia. Jakarta. 1987

Mariana, Dede. Memahami Undang-Undang Nomor 22 Tahun 1999 dan Undang-Undang Nomor 32 Tahun 2004 Tentang Pemerintahan Daerah. Majalah Governance, Pusat Penelitian Kebijakan Publik dan QE Journal |Vol.05 - No. 04 Desember 2016 - 206 
Pengembangan Wilayah Lembaga Penelitian Universitas Padjadjaran Bandung, Juni 2005

Mansyuri, R. Panduan Konsep Utama Pajak Penghasilan Indonesia. PT Bina Rena Pariwara. Jakarta. 1994

Mardiasmo, Otonomi Dan Manajemen Keuangan Daerah. Jakarta : Andi 2002

Musgrave, Richard A. dan Peggy Musgrave. Keuangan Negara dalam Teori dan Praktek (edisi Bahasa Indonesia) Penerbit Erlangga Jakarta 1993

Nordin, Pajak Daerah Sebagai Sumber Pendapatan Daerah Kabupaten/Kota Di Era Otonomi Daerah. Dalam DELEGASI Jurnal Ilmu Administrasi No 2 Agustus 2005 STIA Banjarmasin

Prasentiantono, Tony A (ed.) Kebijakan Ekonomi Publik di Indonesia, Substansi dan Urgensi : Kumpulan Tulisan Dr.Guritno Mangkusubroto, Gramedia Pustaka Utama, Jakarta, 1994

Pamoedji, S. Pembinaan Perkotaan di Indonesia. Penerbit Ichtiar. Jakarta. 1980

Pattimura, Luthfi. Manajamen Otonomi Daerah. LKSPI. Jakarta. 2003

Piliang, Indra J. Otonomi Daerah Evaluasi dan Proyeksi. Divisi Kajian Demokrasi Lokal Yayasan Harkat Bangsa. Jakarta 2003

Rachbini, Didik.J. Politik Deregulasi Dan Agenda Kebijakan Ekonomi. Info Bank. Jakarta. 1994

Rasyid, Ryas. Perspektif Otonomi Luas, di dalam Otonomi atau Federalisme, Dampaknya terhadap Perekonomian, Suara Pembaruan, Jakarta 2000

Radianto, Otonomi Keuangan Daerah Tingkat II Maluku, Prisma, LP3ES Jakarta. 1997.

Salomo, Roy V dan M. Ikhsan. Keuangan Daerah di Indonesia. STIA LAN Press Jakarta 2002

Sarundajang. Arus Balik Kekuasaan Pusat Ke Daerah. Sinar Harapan, Jakarta, 1999

Sidik, Machfud, Keuangan Daerah. Modul Universitas Terbuka. Penerbit Universitas Terbuka. Jakarta.1996

Sidik, Machfud. Optimalisasi Pajak Daerah Dan Retribusi Daerah Dalam Rangka Peningkatkan Kemampuan Keuangan Daerah. disampaikan

QE Journal | Vol.05 - No. 04 Desember 2016 - 207 
dalam Acara Orasi Ilmiah dengan Thema "Strategi Meningkatkan Kemampuan Keuangan daerah Melalui Penggalian Potensi Daerah Dalam Rangka Otonomi Daerah" Acara Wisuda XXI STIA LAN Bandung Tahun Akademik 2001/2002 - di Bandung, 10 April 2002.

Smith, B.C. Decentralization: The Territorial Dimension Of The State. George Allen \& Unwin. London. 1985.

Simanjuntak, Robert.A. Otonomi Daerah dan Desentralisasi Fiskal, Kajian Hubungan Keuangan Pusat-Daerah Pasca Orde Baru, disampaikan sebagai bahan Seminar \& Dialog Nasional "Platform Untuk Masa Depan Ekonomi Indonesia". Diselenggarakan ISEI Cbg Padang dengan IRIS Univ.Marryland serta USAID. Padang, 15-16 April 1999.

Surbakti, Ramlan. Otonomi Daerah Seluas-luasnya dan Faktor Pendukungnya. www.otoda.or.id. Tanpa tahun

Soelarno, Slamet. Pajak Daerah Dan Retribusi Daerah. STIA LAN Press. Jakarta.1999

Toha, Mahmud dan M. Soekarni. Studi Kelayakan Ekonomi, Pembentukan Propinsi Baru: Kasus Banten. Jurnal Ekonomi Pembangunan. Jakarta. 2000

United Nation, Public Administration in Second United Development Decade, Departement of Economic and Social Affair, United Nation, New York, 1971

Uppal, J.S. Taxation in Indonesia. Yogyakarta : Gadjah Mada University Press. 2000

Waldo, Dwight. Pengantar Studi Public Administration. Terjemahan Selamet W. Admosoedarmo. Cetakan keenam. Radar Jaya Offset. Jakarta.1991

White, Leonard D. Introduction To The Study Of Public Administration. Fourth Edition. The Mc Millan Co. New York.1958

Widjaja, A.W. Titik Berat Otonomi pada Daerah Tingkat II. Jakarta. Rajawali Press, 1998

Zandjani, Tubagus Chairul Amachi. Perpajakan. Gramedia. Jakarta. 1992

QE Journal | Vol.05 - No. 04 Desember 2016 - 208 